American Journal of Environmental Sciences 8 (2): 162-169, 2012

ISSN 1553-345X

(C) 2012 Science Publications

\title{
Drinking Water Quality Assessment in Tetova Region
}

\author{
${ }^{1}$ Durmishi, B.H., ${ }^{2}$ M. Ismaili, ${ }^{1}$ A. Shabani, ${ }^{1}$ Sh. Abduli \\ ${ }^{1}$ Department of Chemistry, Faculty of Natural Science, \\ State University of Tetova, Ilidenska bb, 1200 Tetova, Macedonia \\ ${ }^{2}$ Insitute for Environment and Health-IEH, South East European University-SEEU, \\ Ilidenska bb, 1200 Tetova, Macedonia
}

\begin{abstract}
Problem statement: The quality of drinking water is a crucial factor for human health. The objective of this study was the assessment of physical, chemical and bacteriological quality of the drinking water in the city of Tetova and several surrounding villages in the Republic of Macedonia for the period May 2007-2008. The sampling and analysis are conducted in accordance with State Regulation No. 57/2004, which is in compliance with EU and WHO standards. A total of 415 samples were taken for chemical, physical and bacteriological analysis. Approach: We had used the Canadian Drinking Water Quality Index (DWQI) for the quality assessment of drinking water. Results: The results of the samples taken in Tetova point to better hygienic and sanitary conditions than in the rural drinking network, mainly due to improper disinfection practices. The results show that the highest water quality was recorded at the SEEU $(\mathrm{DWQI}=92.69)$, whereas the lowest quality at Shipkovica $(\mathrm{DWQI}=63.18)$. Conclusion: This study strongly recommends the immediate correction of these issues to protect the health of population from water borne diseases as well as regular monitoring of the drinking water quality in the region.
\end{abstract}

Key words: Drinking water quality, drinking water quality index, bacteriological parameters, physical-chemical parameters, public health, bacteriological analysis, borne diseases, world health organization

\section{INTRODUCTION}

Environmental pollution and especially the contamination of water sources is a problem facing society today. The increasing urbanization, industrialization, the modernization of agriculture, the increase in traffic contribute to global pollution, which requires accurate monitoring and information about the quality of water resources.

The World Health Organization (WHO) estimated that in developing countries about $80 \%$ of water pollution is a result of domestic waste. Moreover, the inadequate management of water systems can cause serious problems in the availability and quality of water (Krishnan et al., 2007).

During the past decade, widespread reports of ground water contamination have increased public concern about drinking water quality (Yanggen and Born, 1990). Accumulated sewage can find its way into damaged water supply systems. Thus, improper maintenance is an additional factor of water pollution.
Drinking water quality directly affects human health. The impacts reflect the level of contamination of the whole drinking water supply system (raw water, treatment facilities and the distribution network to consumers) (Magnuss, 2009). Drinking water is an essential environmental constituent and the quality of drinking water is an issue of primary interest for the residents of the European Union (Chirila et al., 2010). Failure to provide effective treatment of water sources and safe distribution can expose the community to the risk of disease outbreaks as well as other adverse health effects. Unfortunately in many countries across the world, drinking water supplies are contaminated and this has affected the health and the economic status of the population.

Monitoring of drinking water quality is an important component of water management, while data analysis is necessary for the identification and characterization of water quality problems. Assessment is the process by which water quality data is transformed into information. The information gained from monitoring is essential for assessing water quality.

Corresponding Author: Durmishi, B.H., Department of Chemistry, State University of Tetova, Ilidenska bb, 1200 Tetova, Macedonia Tel: 072/702 862 
Monitoring can also verify water pollution following it with corrective action. Public water supply systems are required to perform microbiological, chemical, physical and radiological monitoring of their drinking water to determine the presence of any regulated contaminants. The levels of detected contaminants are used to determine compliance with a Maximum Contaminant Level (MCL) and to evaluate the need for additional treatment. Detection of a contaminant in the water may require public notification and, in the case of an MCL violation, the notification must include health effects information and the need for an alternate water supply (CWQCC, 2006).

Chemical contamination of drinking water is often considered a lower priority than microbial contamination by regulators, because adverse health effects from chemical contaminations are generally associated with long-term exposures, whereas the effects from microbial contamination are usually immediate (WHO, 2007). There are some researches in the field of chemical and microbial contamination of the drinking water in our region (Dabevska-Kostoska $e t$ al., 2007). Nonetheless, chemical contamination can affect the taste and appearance of water, lead to community anger, detrimental economic impacts and in some cases serious morbidity (Thompson, 2006; Parvez et al., 2006).

The quality of drinking water has a powerful impact on public health and therefore effective monitoring and comprehensive assessment of public drinking water supply systems are crucial to protect the wellbeing of the public and to allow implementation of a preventive approach to manage drinking water quality (Li et al., 2009). Contaminants such as bacteria, viruses, heavy metals, nitrates and salt have found their way into water supplies as a result of inadequate treatment and disposal of human and agricultural waste, industrial discharges and over-use of limited water resources. Even if no sources of anthropogenic contamination exist, there is potential for natural levels of metals and other chemicals to be harmful to human health (Akoto and Adiyiah, 2007)

The drinking water analysis for bacteriological and physical-chemical properties are essential for public health studies. The bacteriological analysis determines the potability of water. The provision of potable drinking water for rural and urban areas is necessary to prevent the dangers of water diseases and public health prevention. Potable water has to comply with certain physical, chemical and microbiological standards (Okonko et al., 2008), which should not contain microorganisms and chemicals at harmful levels (Arunabh and Bhatt, 2008).

Water borne diseases are the most dangerous ones in terms of public health, because they can easily spread
(Ozdemir et al., 2010). According to the WHO, there were an estimated 4 billion cases of diarrhoea and 2.2 million deaths annually. The consumption of unsafe water has been implicated as one of the major causes of this disease (Chan et al., 2007). Diarrhoea is the major cause of death for more than 2 million people per year worldwide, mostly children under the age of five (Zamxaka et al., 2004), as a result of infection or the result of a combination of a variety of enteric pathogens.

Review of literature: The assessment of water quality is done in various ways. A very powerful tool for this purpose is the Water Quality Index (WQI). A water quality index is a means to summarize large amounts of water quality data into simple terms (e.g., good, bad) for reporting to management and the public in a consistent manner. Researchers use different types of indices. The objective of an index is to turn multifaceted water quality data into simple information that is comprehensible and useable by the public (Alam and Pathak, 2010). In 1965, Horton for the first time formulated a water quality index and then it was used by many researchers for different types of water. The WQI represents a simple number from 0-100 where a highest value indicates the best quality water and vice versa (Li et al., 2009; Samantray et al., 2009; Parmar and Parmar, 2010; Shilpi and Gangal, 2010; Napacho and Manyele, 2010).

According to by numerous authors the different statistical approaches were followed for analyzing water quality data based on rank order of observations and factor analysis and WQI was applied to river water and water coast. In 2006, Hulya Boyacioglu has developed a new index called the "Universal Water Quality Index (UWQI)', by studying the supranational standard, i.e., the European Community Standard (Boyacioglu, 2007). In general, water quality indices incorporate data from multiple water quality parameters into a mathematical equation that rates the health of a water body with a number.

The objective of this study is the drinking water quality assessment in the city of Tetova and several surrounding villages in the Republic of Macedonia. Monitored parameters of the samples were also determined by using standard analytical methods. We have used the Canadian Drinking Water Quality Index (DWQI) to evaluate the drinking water quality as well as the mathematical processing of the data.

\section{MATERIALS AND METHODS}

Description of the study area: The study area includes the city of Tetova and its mountain villages Sellca, Gjerma, Shipkovica and Kodra e Diellit (Popova Shapka). Tetova is the largest city of Pollog and second after 
Skopje in the R. of Macedonia. Residents of this area obtain their drinking water from surface sources and as well as from the Sharr mountain.

Tetova municipality is located in the northwest of Macedonia, with an area about $1080 \mathrm{~km}^{2}$ which represents $4.2 \%$ of the whole country (Durmishi, 2005) with around 80000 inhabitants. The region of Tetova has a continental climate, influenced by the Sharr mountain massif as well as a Mediterranean influence in increasing the temperature in the summer. The average value of rainfalls ranges from $480-600 \mathrm{~mm}$ and in October, November to March fall about two thirds of their annual average. The abundant rains in the autumn and spring represent a prerequisite for this region to have water.

Collection of samples: Taking samples for analysis was done from May 2007 to April 2008 according to recommended procedures (Durmishi, 2005; GRM, 2004). Drinking water samples were collected from seven locations (1-4 villages and 5-7 city): 1-Village Sellca, 2Village Gjerma, 3-Village Shipkovica, 4-Dwellings Kodra e Diellit, 5-the city of Tetova, 6-Reservoir before chlorination and 7-South East European University-which uses under-ground water from a well. Samples for bacteriological analysis were collected in glass bottles cleaned with detergent, diluted $\mathrm{HNO}_{3}$ and de-ionized water and distilled twice, while those for physicalchemical analysis in polyethylene bottles, respectively. Before sampling, bottles were rinsed three times with sampled water, they were labelled with the date of the name of the source of samples and then are transferred to hand refrigerator $\left(4^{\circ} \mathrm{C}\right)$ to be analyzed in the chemical and bacteriological laboratories of the Centre for Health Protection of Tetova. All tests were performed at least three times to calculate the average value.

Reagents, solutions and instruments: Analytical grade chemicals were used for preparing all reagents and solutions. De-ionized and twice distilled water was used in all experiments. Before each analysis, all instruments are calibrated according to manufacturer's recommendations. $\mathrm{pH}$ was measured using $\mathrm{HACH} \mathrm{pH}$ meter model with a combined electrode and turbidity with turbidimeter. Electrical conductivity is measured by conductometer. A hach dr 2000 spectrophotometer is used for spectrophotometric measurements.

Physical, physical-chemical and bacteriological analysis: Analyses are performed taking into account requirements (testing methods, sampling frequencies, precision and required accuracy, the maximum allowed value - MAA of parameters) for drinking water in the R. of Macedonia under "Drinking Water Regulation, Official Gazette Republic of Macedonia no. 57/2004, which is consistent with EU and WHO standards. To assess the quality of drinking water physical, physicalchemical and bacteriological parameters are measured, which supply the network of the city of Tetova are monitored three times a week at 5 different sampling points, while the supply of rural settlements systems are followed in 2 seasonal sampling points (Sellca), 2 sampling points (Gjerma), 3 sampling points (Shipkovica), 4 sampling points (Kodra e Diellit), 1 sampling points Reservoir Before Chlorination (RBC) and 2 sampling points (SEE University) respectively.

Of the 15 physical-chemical parameters, residual chlorine is measured in the field (colorimetric method with tetrametil benzidine), colour (colorimetric method with the help of Pt-Co scale), wind (organoleptic method at a temperature 25 and $40^{\circ} \mathrm{C}$ ), taste (organoleptic method at temperature 12 and $25^{\circ} \mathrm{C}$ ), turbidity (turbidimetric method with formazine standard), the total residue after of evaporation, TRAE (gravimetric method), chemical expense $\mathrm{KMnO}_{4}$, COD (volumetric method by Thiemann Küebel boiling in acidic environment), $\mathrm{pH}$ (potentiometric method) and electric conductivity, EC (conductometric method), chlorides (argentometric titrimetric method), with spectrophotometric method (HACH recommended by USPA) be determined ammonia, nitrites, nitrates, iron and manganese in accordance with the "Drinking Water Regulation, Official Gazette of R. Macedonia no. 57/2004' 'of 2004.

For measurement of 12 bacteriological parameters: the Total Coliform Bacteria (TCB), Coliform Bacteria with Faecal Origin (CBFO), the total number of aerobic mesofile bacteria (TNAMB), Streptococci with Faecal Origin (SFO), Sulphide-Reduction Clostridies (SRC), Proteus Species (PS), Pseudomonas Aurigunosa (PA), Thermo Tolerant Coliform Bacteria (THCB), Esheria coli (EK), Clostridium Perifringens (CP), the number of colonies at $22^{\circ} \mathrm{C}\left(\mathrm{NC} 22^{\circ} \mathrm{C}\right)$ and number of colonies at $37^{\circ} \mathrm{C}\left(\mathrm{NC} 37^{\circ} \mathrm{C}\right)$ is used method of determining the most reliable number and membrane filter method of the same state regulation.

Drinking Water Quality Index: To assess the quality of drinking water we used the Drinking Water Quality Index (DWQI) developed by the Canadian Council of Ministers of the Environment, which is widely used. The DWQI includes three measures of variance from the selected drinking water quality objectives-scope $\left(\mathrm{F}_{1}\right)$, frequency $\left(\mathrm{F}_{2}\right)$ and amplitude $\left(\mathrm{F}_{3}\right)$ (CCME, 2001).

The scope represents the water quality of the legal norm of non-compliance during the period of interest and it express Eq. 1:

$F_{1}=\left(\frac{\text { Number of failed variales }}{\text { Total number of variables }}\right) \cdot 100$

The frequency characterizes the percentage of individual tests that do not meet objectives Eq. 2: 
Am. J. Environ. Sci., 8 (2): 162-169, 2012

$$
\mathrm{F}_{2}=\left(\frac{\text { Number of failed tests }}{\text { Total number of tests }}\right) \cdot 100
$$

The amplitude represents the amount by which failed tests do not meet their objectives Eq. 3:

$$
\mathrm{F}_{3}=\left(\frac{\mathrm{nse}}{0.01 \mathrm{nse}+0.01}\right)
$$

where, nse indicates the normalized sum of excursions that is the collective amount by which individual tests are out of compliance.

The DWQI is then calculated as Eq. 4:

$$
\text { DWQI }=100-\left(\frac{\sqrt{\mathrm{F}_{1}^{2}+\mathrm{F}_{2}^{2}+\mathrm{F}_{3}^{2}}}{1.732}\right)
$$

This score is then ranked into one of the following five categories (CCME, 2001):

Excellent: (DWQI Value 95-100)-Water protected with a virtual absence of impairment; conditions are very close to pristine levels; these index values can only be obtained if all measurements meet recommended guidelines virtually all of the time.

Very good: (DWQI Value 89-94)-Water Quality Is protected with a slight presence of impairment; conditions are close to pristine levels.
Good: (DWQI Value 80-88)-Water Quality Is protected with only a minor degree of impairment; conditions rarely depart from desirable levels.

Fair: (DWQI Value 65-79)-Water Quality Is usually protected but occasionally impaired; conditions sometimes depart from desirable levels.

Marginal: (DWQI Value 45-64)-Water Quality Is frequently impaired; conditions often depart from desirable levels.

Poor: (WQI Value 0-44)-Water Quality Is almost always impaired; conditions usually depart from desirable levels.

Excel and Sigma Plot software's were used for statistical analysis of data and to construct graphs.

\section{RESULTS}

The results of the study are presented in the Table 1-7 and the Fig. 1-7. A total of 415 samples were taken and 9168 tests conducted, of which 6118 physical-chemical and 3050 bacteriological. Table 1 shows that the water quality in villages is more frequently impaired than in the city of Tetova and its water reservoir. The majority of impaired quality is a result of residual chlorine. At the SEEU sampling point the water quality is not affected by the aforementioned impairments due to UV disinfection.

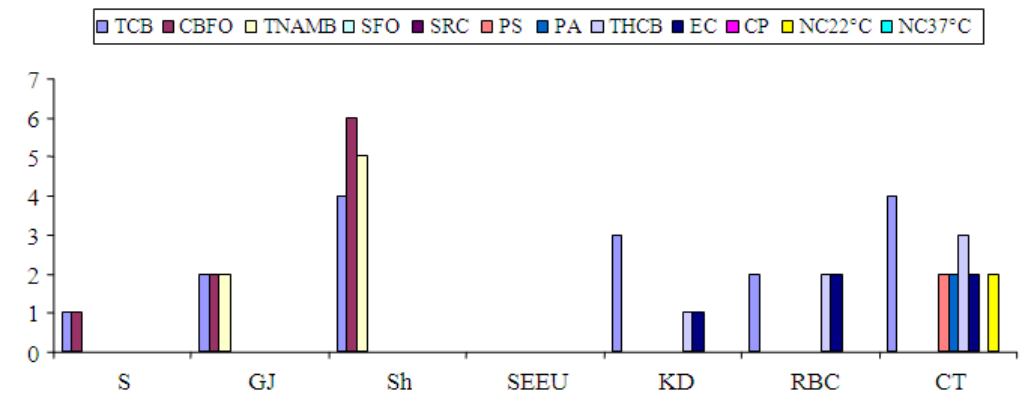

Fig. 1: Variation of irregular bacteriological tests

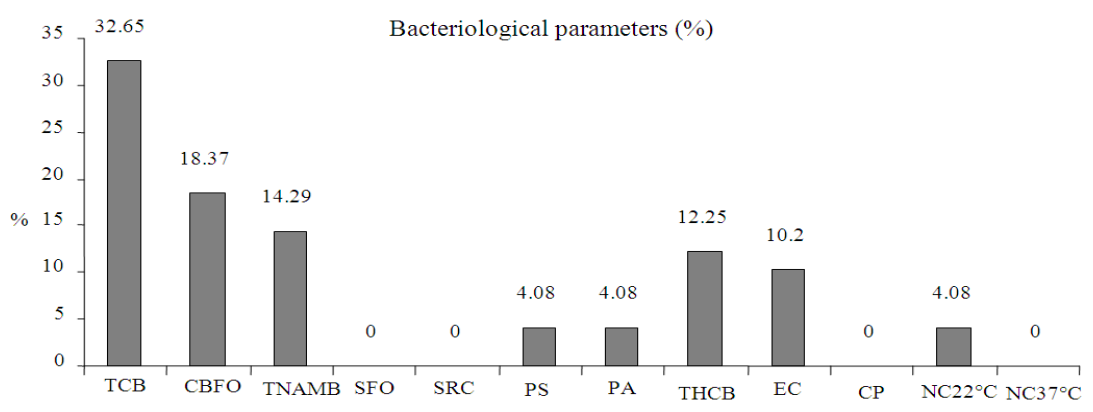

Fig. 2: The percentage of irregular bacteriological tests 
Am. J. Environ. Sci., 8 (2): 162-169, 2012

Table 1: General statistics

\begin{tabular}{|c|c|c|c|c|c|c|}
\hline \multirow[b]{3}{*}{ Sample site } & \multicolumn{6}{|c|}{ Analysed samples/Analysed tests } \\
\hline & \multicolumn{3}{|c|}{ Physical-chemical analysis } & \multicolumn{3}{|c|}{ Bacteriological analysis } \\
\hline & Total & Irregular & $(\%)$ & Total & Irregular & $(\%)$ \\
\hline S & $4 / 60$ & $4 / 4$ & $100 / 6.67$ & $4 / 28$ & $1 / 2$ & $25.00 / 7.140$ \\
\hline GJ & $4 / 60$ & $4 / 4$ & $100 / 6.67$ & $4 / 28$ & $2 / 6$ & $50.00 / 21.43$ \\
\hline SH & $8 / 120$ & $8 / 8$ & $100 / 6.67$ & $8 / 56$ & $6 / 15$ & $75.00 / 26.79$ \\
\hline KD & $20 / 285$ & $20 / 20$ & $100 / 7.02$ & $20 / 152$ & $3 / 5$ & $15.00 / 3.290$ \\
\hline $\mathrm{RBC}$ & $32 / 466$ & $0 / 0$ & $0.00 / 0.00$ & $32 / 238$ & $2 / 6$ & $6.25 / 2.520$ \\
\hline SEEU & $8 / 120$ & $8 / 8$ & $100 / 6.67$ & $8 / 56$ & $0 / 0$ & $0.00 / 0.000$ \\
\hline CT & $339 / 5007$ & $115 / 115$ & $33.92 / 2.30$ & $339 / 2548$ & $9 / 15$ & $2.65 / 0.860$ \\
\hline Total: & $415 / 6118$ & $159 / 159$ & $38.31 / 2.60$ & $415 / 3050$ & $23 / 49$ & $5.54 / 1.610$ \\
\hline
\end{tabular}

S-Village Sellca, GJ-Village Gjerma, SH-Village Shipkovica, KD-Dwellings Kodra e Diellit (Popova Shapka), RBC-Reservoir before chlorination, SEEU-South East European University and CT-City of Tetova

Table 2: Bacteriological analysis results

\begin{tabular}{|c|c|c|c|c|c|c|}
\hline Site & TCB & CBFO & TNAMB & SFO & SRC & PS \\
\hline $\mathrm{S}$ & $\begin{array}{l}3.00 \pm 3.00 \\
(0.00-12.00)\end{array}$ & $\begin{array}{l}3.00 \pm 3.00 \\
(0.00-12.00)\end{array}$ & $\begin{array}{l}25.00 \pm 25.00 \\
(0.00-100.00)\end{array}$ & 0 & 0 & 0 \\
\hline $\mathrm{Gj}$ & $\begin{array}{l}8.00 \pm 4.62 \\
(0.00-16.00)\end{array}$ & $\begin{array}{l}8.00 \pm 4.62 \\
(0.00-16.00)\end{array}$ & $\begin{array}{l}56.25 \pm 32.49 \\
(0.00-115.00)\end{array}$ & 0 & 0 & 0 \\
\hline Sh & $\begin{array}{l}8.00 \pm 3.02 \\
(0.00-16.00)\end{array}$ & $\begin{array}{l}12.00 \pm 2.62 \\
(0.00-16.00)\end{array}$ & $\begin{array}{l}95.00 \pm 22.42 \\
(0.00-180.00)\end{array}$ & 0 & 0 & 0 \\
\hline $\mathrm{KD}$ & $\begin{array}{l}2.40 \pm 1.31 \\
(0.00-16.00)\end{array}$ & 0 & 0 & 0 & 0 & 0 \\
\hline SEEU & $\begin{array}{l}0 \\
0.13 \pm 0.07\end{array}$ & $\begin{array}{l}0 \\
0\end{array}$ & $\begin{array}{l}0 \\
0\end{array}$ & $\begin{array}{l}0 \\
0\end{array}$ & $\begin{array}{l}0 \\
0\end{array}$ & $\begin{array}{l}0 \\
0.05 \pm 0.04\end{array}$ \\
\hline
\end{tabular}

TCB-total Coliform Bacteria, CBFO-coliform bacteria with faecal origin, TNAMB-the total number of aerobic mesofile bacteria, SFO-Streptococci with Faecal Origin, SRC-Sulphide-Reduction Clostridies and PS-Proteus Species

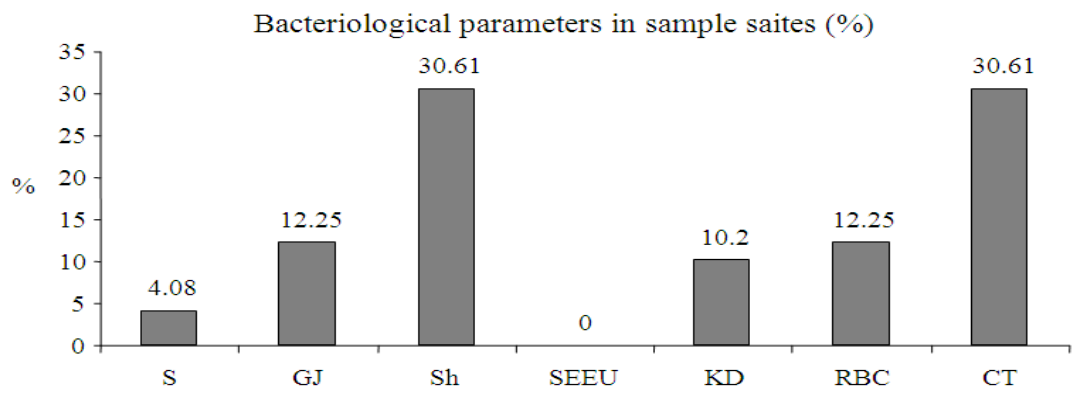

Fig. 3: The percentage of irregular bacteriological tests versus locations

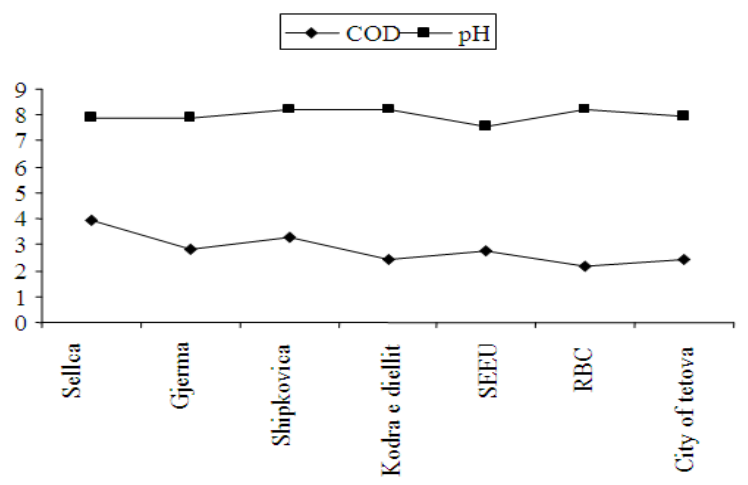

Fig. 4: $\mathrm{COD}$ and $\mathrm{pH}$ variations

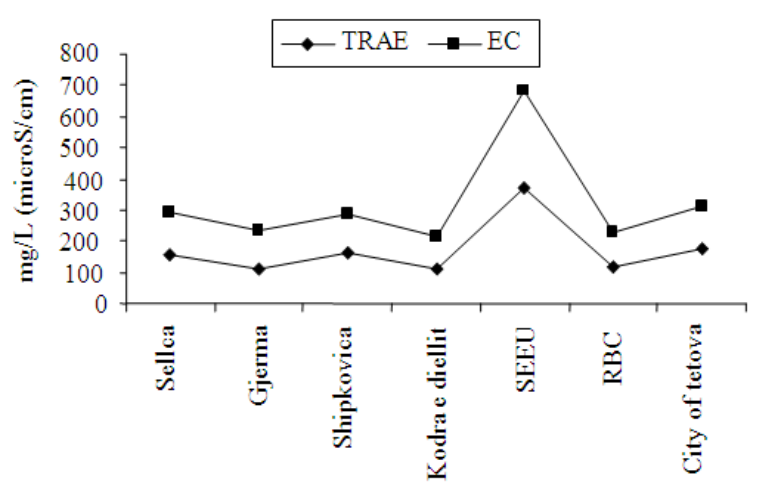

Fig. 5: EC and TRAE variations 
Am. J. Environ. Sci., 8 (2): 162-169, 2012

Table 3: Bacteriological analysis results (continued)

\begin{tabular}{lllllll}
\hline Site & PA & THCB & EK & CP & NC22 $2^{\circ} \mathrm{C}$ & $\mathrm{NC} 37^{\circ} \mathrm{C}$ \\
\hline S & 0 & $\mathrm{~nm}$ & $\mathrm{~nm}$ & $\mathrm{~nm}$ & $\mathrm{~nm}$ & $\mathrm{~nm}$ \\
GJ & 0 & $\mathrm{~nm}$ & $\mathrm{~nm}$ & $\mathrm{~nm}$ & $\mathrm{~nm}$ & $\mathrm{~nm}$ \\
Sh & 0 & $1.33 \pm 1.33$ & $1.67 \pm 1.67$ & $\mathrm{~nm}$ & $\mathrm{~nm}$ & $\mathrm{~nm}$ \\
KD & 0 & $(0.00-16.00)$ & $(0.00-20.00)$ & & 0 & 0 \\
& & $\mathrm{~nm}$ & $\mathrm{~nm}$ & $\mathrm{~nm}$ & $\mathrm{~nm}$ & $\mathrm{~nm}$ \\
SEEU & 0 & $2.29 \pm 1.55$ & $12.14 \pm 10.70$ & 0 & 0 & 0 \\
RBC & 0 & $(0.00-16.00)$ & $(0.00-150.00)$ & & & $0.06 \pm 0.04$ \\
CT & $0.04 \pm 0.03$ & $0.81 \pm 0.64$ & $0.86 \pm 0.73$ & 0 & 0 & $(0.00-5.30)$
\end{tabular}

nm-not measured, PA-Pseudomonas Aurigunosa, THCB-Thermo Tolerant Coliform Bacteria, EK-esheria coli, CP-Clostridium Perifringens, NC22 ${ }^{\circ} \mathrm{C}$ the number of colonies at $22^{\circ} \mathrm{C}$ and $\mathrm{NC} 37^{\circ} \mathrm{C}$-number of colonies at $37^{\circ} \mathrm{C}$

Table 4: Distribution of irregular bacteriological tests

\begin{tabular}{|c|c|c|c|c|c|c|c|c|c|}
\hline & $\mathrm{S}$ & $\mathrm{Gj}$ & $\mathrm{Sh}$ & SEEU & KD & $\mathrm{RBC}$ & CT & Total & $\%$ \\
\hline TCB & 1.00 & 2.00 & 4.00 & 0 & 3.0 & 2.00 & 4.00 & 16 & 32.65 \\
\hline CBFO & 1.00 & 2.00 & 6.00 & 0 & 0.0 & 0.00 & 0.00 & 9 & 18.37 \\
\hline TNAMB & 0.00 & 2.00 & 5.00 & 0 & 0.0 & 0.00 & 0.00 & 7 & 14.29 \\
\hline SFO & 0.00 & 0.00 & 0.00 & 0 & 0.0 & 0.00 & 0.00 & 0 & 0.000 \\
\hline SRC & 0.00 & 0.00 & 0.00 & 0 & 0.0 & 0.00 & 0.00 & 0 & 0.000 \\
\hline PS & 0.00 & 0.00 & 0.00 & 0 & 0.0 & 0.00 & 2.00 & 2 & 4.080 \\
\hline PA & 0.00 & 0.00 & 0.00 & 0 & 0.0 & 0.00 & 2.00 & 2 & 4.080 \\
\hline THCB & $\mathrm{nm}$ & $\mathrm{nm}$ & $\mathrm{nm}$ & 0 & 1.0 & 2.00 & 3.00 & 6 & 12.25 \\
\hline EK & $\mathrm{nm}$ & $\mathrm{nm}$ & $\mathrm{nm}$ & 0 & 1.0 & 2.00 & 2.00 & 5 & 10.20 \\
\hline $\mathrm{CP}$ & $\mathrm{nm}$ & $\mathrm{nm}$ & $\mathrm{nm}$ & 0 & 0.0 & 0.00 & 0.00 & 0 & 0.000 \\
\hline $\mathrm{NC} 22^{\circ} \mathrm{C}$ & $\mathrm{nm}$ & $\mathrm{nm}$ & $\mathrm{nm}$ & 0 & 0.0 & 0.00 & 2.00 & 2 & 4.080 \\
\hline $\mathrm{NC} 37^{\circ} \mathrm{C}$ & $\mathrm{nm}$ & $\mathrm{nm}$ & $\mathrm{nm}$ & 0 & 0.0 & 0.00 & 0.00 & 0 & 0.000 \\
\hline Total & 2.00 & 6.00 & 15.00 & 0 & 5.0 & 6.00 & 15.00 & 49 & 100.00 \\
\hline$\%$ & 4.08 & 12.25 & 30.61 & 0 & 10.2 & 12.25 & 30.61 & 100 & \\
\hline
\end{tabular}

nm-not measured, TCB-total Coliform Bacteria, CBFO-coliform bacteria with faecal origin, TNAMB-the Total Number of Aerobic mesofile Bacteria, SFO-streptococci with faecal origin, SRC-Sulphide-Reduction Clostridies, PS-Proteus Species, PA-Pseudomonas Aurigunosa, THCB-Thermo tolerant coliform bacteria, EK-esheria coli, CP-Clostridium Perifringens, $\mathrm{NC} 22^{\circ} \mathrm{C}$-the number of colonies at $22^{\circ} \mathrm{C}$ and $\mathrm{NC} 37^{\circ} \mathrm{C}$-number of colonies at $37^{\circ} \mathrm{C} \mathrm{S}$ Village Sellca, GJ-Village Gjerma, SH-Village Shipkovica, KD-Village Kodra e Diellit (Popova Shapka), RBF-Reservoir before chlorination, SEEU-South East European University and CT-City of Tetova

Table 5: Physical and chemical analysis results

\begin{tabular}{|c|c|c|c|c|c|c|c|}
\hline Site & Colour & Wind & Taste & Turbidity & Residual $\mathrm{Cl}_{2}$ & $\mathrm{pH}$ & COD \\
\hline $\mathrm{S}$ & none & none & none & 0 & 0 & $\begin{array}{l}7.87 \pm 0.05 \\
(7.78-8.02)\end{array}$ & $\begin{array}{l}3.93 \pm 0.38 \\
(3.26-5.02)\end{array}$ \\
\hline $\mathrm{Gj}$ & none & none & none & 0 & 0 & $\begin{array}{l}7.91 \pm 0.14 \\
(7.67-8.25)\end{array}$ & $\begin{array}{l}2.81 \pm 0.30 \\
(2.14-3.46)\end{array}$ \\
\hline Sh & none & none & none & 0 & 0 & $\begin{array}{l}8.184 \pm 0.049 \\
(8.02-8.37)\end{array}$ & $\begin{array}{l}3.313 \pm 0.185 \\
(2.46-3.88)\end{array}$ \\
\hline $\mathrm{KD}$ & none & none & none & $\begin{array}{l}0.05 \pm 0.024 \\
(0.00-0.30)\end{array}$ & 0 & $\begin{array}{l}8.226 \pm 0.024 \\
(8.10-8.42)\end{array}$ & $\begin{array}{l}2.422 \pm 0.117 \\
(1.55-3.79)\end{array}$ \\
\hline SEEU & none & none & none & 0 & 0 & $\begin{array}{l}7.561 \pm 0.096 \\
(7.15-7.84)\end{array}$ & $\begin{array}{l}2.790 \pm 0.098 \\
(2.53-3.22)\end{array}$ \\
\hline $\mathrm{RBC}$ & none & none & none & 0 & 0 & $\begin{array}{l}8.177 \pm 0.024 \\
(7.92-8.52)\end{array}$ & $\begin{array}{l}2.184 \pm 0.09 \\
(1.26-3.45)\end{array}$ \\
\hline CT & none & none & none & $\begin{array}{l}0.003 \pm 0.002 \\
(0.00-0.40)\end{array}$ & $\begin{array}{l}0.16 \pm 0.011 \\
(0.00-2.00)\end{array}$ & $\begin{array}{l}7.95 \pm 0.019 \\
(7.02-8.40)\end{array}$ & $\begin{array}{c}2.425 \pm 0.037 \\
(0.62-5.68)\end{array}$ \\
\hline
\end{tabular}

COD-Chemical oxygen demand, S-Village Sellca, GJ-Village Gjerma, SH-Village Shipkovica, KD-Village Kodra e Diellit (Popova Shapka), RBF-Reservoir before chlorination, SEEU-South East European University and CT-City of Tetova

Table 6: Physical-chemical analysis (continued)

\begin{tabular}{|c|c|c|c|c|c|c|c|c|}
\hline Site & TRAE & $\mathrm{EC}$ & $\mathrm{NH}_{3}$ & $\mathrm{NO}_{2}^{-}$ & $\mathrm{NO}_{3}^{-}$ & $\mathrm{Cl}^{-}$ & $\mathrm{Fe}$ & $\mathrm{Mn}$ \\
\hline S & $\begin{array}{l}154.75 \pm 43.28 \\
(90-282)\end{array}$ & $\begin{array}{l}294.5 \pm 87.9 \\
(178-556)\end{array}$ & 0 & 0 & $\begin{array}{l}0.88 \pm 0.17 \\
(0.50-1.20)\end{array}$ & $\begin{array}{l}5.25 \pm 3.85 \\
(1.30-16.80)\end{array}$ & 0 & 0 \\
\hline $\mathrm{Gj}$ & $\begin{array}{l}112.75 \pm 3.17 \\
(105-120)\end{array}$ & $\begin{array}{l}233.8 \pm 14.2 \\
(205-265)\end{array}$ & 0 & $\begin{array}{l}0.001 \pm 0.001 \\
(0.00-0.004)\end{array}$ & $\begin{array}{l}1.65 \pm 0.85 \\
(0.60-4.20)\end{array}$ & $\begin{array}{l}2.60 \pm 1.47 \\
(0.80-7.00)\end{array}$ & 0 & 0 \\
\hline Sh & $\begin{array}{l}165.25 \pm 4.39 \\
(152-181)\end{array}$ & $\begin{array}{l}288 \pm 3.24 \\
(275-298)\end{array}$ & 0 & & $\begin{array}{l}0.34 \pm 0.22 \\
(0.00-1.80)\end{array}$ & $\begin{array}{l}1.39 \pm 0.12 \\
(0.80-2.00)\end{array}$ & 0 & 0 \\
\hline KD & $\begin{array}{l}112.3 \pm 3.1 \\
(95-120)\end{array}$ & $\begin{array}{l}212.7 \pm 4.9 \\
(145-231)\end{array}$ & 0 & 0 & $\begin{array}{l}0.64 \pm 0.13 \\
(0.00-2.30)\end{array}$ & $\begin{array}{l}0.61 \pm 0.086 \\
(0.10-1.40)\end{array}$ & 0 & 0 \\
\hline SEEU & $\begin{array}{l}368 \pm 3.49 \\
(352-379)\end{array}$ & $\begin{array}{l}684.0 \pm 3.1 \\
(672-697)\end{array}$ & 0 & 0 & $\begin{array}{l}6.56 \pm 0.23 \\
(5.70-7.40)\end{array}$ & $\begin{array}{l}13.63 \pm 0.78 \\
(11.50-16.80)\end{array}$ & 0 & 0 \\
\hline $\mathrm{RBC}$ & $\begin{array}{l}116.78 \pm 1.95 \\
(105-141)\end{array}$ & $\begin{array}{l}225.6 \pm 2.6 \\
(179-250)\end{array}$ & 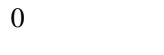 & 0 & $\begin{array}{l}0.70 \pm 0.16 \\
(0.00-3.80)\end{array}$ & $\begin{array}{l}1.80 \pm 0.66 \\
(0.40-21.80)\end{array}$ & 0 & 0 \\
\hline CT & $\begin{array}{l}178.0 \pm 9.9 \\
(0-552)\end{array}$ & $\begin{array}{l}309.7 \pm 8.8 \\
(107-877)\end{array}$ & $\begin{array}{l}0.002 \pm 0.001 \\
(0.0-0.3)\end{array}$ & $\begin{array}{l}0.001 \pm 0.001 \\
(0.0-0.19)\end{array}$ & $\begin{array}{l}2.07 \pm 0.23 \\
(0.0-30.0)\end{array}$ & $\begin{array}{l}4.80 \pm 0.52 \\
(0.0-62.0)\end{array}$ & $\begin{array}{l}0.00021 \pm 0.00013 \\
(0.0-0.04)\end{array}$ & 0 \\
\hline
\end{tabular}

TRAE-total residue after of evaporation, EC-electric conductance 
Am. J. Environ. Sci., 8 (2): 162-169, 2012

Table 7: DWQI assessment and the categorization of drinking water quality

\begin{tabular}{lllllll}
\hline Sample site & $\mathrm{F}_{1}$ & $\mathrm{~F}_{2}$ & $\mathrm{nse}$ & $\mathrm{F}_{3}$ & DWQI & Category \\
\hline Sellca & 30.000 & 15.000 & -0.15 & -17.650 & 78.12 & Fair \\
Gjerma & 40.000 & 25.000 & -0.25 & -33.330 & 66.65 & Fair \\
Shipkovica & 40.000 & 28.750 & -0.29 & -40.490 & 63.18 & Marginal \\
Kodra e diellit & 21.050 & 8.930 & -0.09 & -9.780 & 85.64 & Good \\
SEEU & 7.140 & 7.140 & -0.07 & -7.630 & 92.69 & Good \\
RBC & 16.670 & 1.440 & -0.01 & -1.460 & 90.30 & Good \\
City of Tetova & 25.000 & 2.130 & -0.02 & -2.180 & 85.46 & Good \\
\hline
\end{tabular}

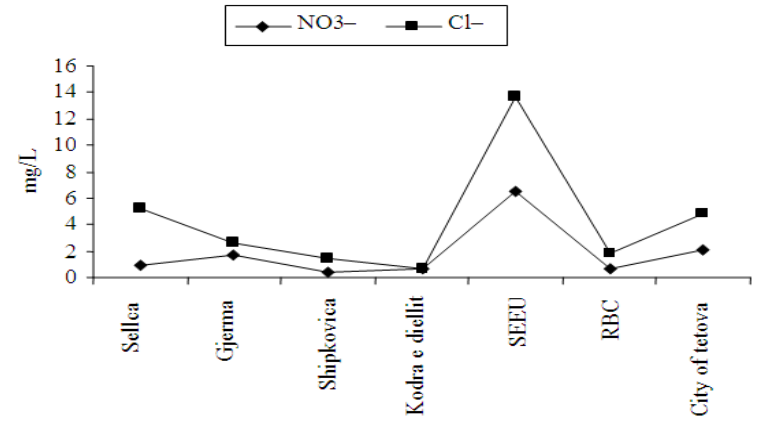

Fig. 6: Nitrates and chlorides variations

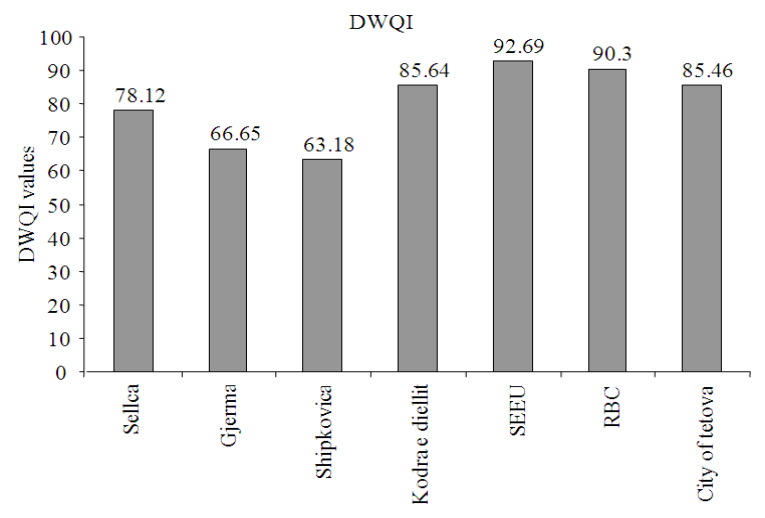

Fig. 7: DWQI assessment result

\section{DISCUSSION}

The results of the bacteriological analysis are presented in the Table 1-3 and 4 and Fig 1-3. Twelve parameters have been analysed. The largest percentage of irregular samples/tests has been found in the village Shipkovica $(75.00-26.79 \%)$, while the best quality at the SEEU $(0.00 / 0.00 \%)$. The total number of irregular bacteriological test was 49 . The $\mathrm{SFO}, \mathrm{SRC}, \mathrm{CP}$ and $\mathrm{NC} 37^{\circ} \mathrm{C}$ parameters have not been found in any of the samples.

The average values are presented in the Table 2 and 3 , with standard deviation as well as the range of bacteriological parameters. The highest value of TNAMB has been detected in the village of Shipkovica $95.00 \pm 22.42$ count $100 \mathrm{~mL}$, while the lowest value for PA, $0.04 \pm 0.03$ count $100 \mathrm{~mL}$, in the city of Tetova, without considering zero values.
The number and percentage of irregular bacteriological tests have been presented in the Fig. 1-3. In the village of Sellca two irregular bacteriological tests, $\mathrm{TCB}$ and CBFO (4.08\%) was found. In Gjerma, irregular was 2 tests TCB, $2 \mathrm{CBFO}$ and 2 TNAMB $(12.25 \%)$.

In Shipkovica, irregular was 15 tests, of which 4 TCB, 6 CBFO and 5 TNAMB (30.61\%). In Kodra e Diellit, irregular was 3 tests TCB, 1 THCB and 1 EK $(10.20 \%)$. The city pre-chlorination reservoir had 6 irregular tests, 2 TCB, 2 THCB and 2 EK (12.25\%).

Table 4 and Fig. 3 shows that a high percentage of irregular bacteriological tests have been found in the city of Tetova-15 tests $(30.61 \%)$. However, this is only in proportion to the total number of irregular test, not the total number of 3050 tests $(1.61 \%)$. The most pristine testing location is the SEEU with 0\% irregular tests.

Figure 2 shows the percentage of irregular bacteriological parameters according to type. The bacteriological analysis resulted in a total of 49 irregular tests, of which 32.65, TCB, 18.37, CBFO, 14.29, TNAMB, 12.25 , THCB, 10.2, EK and $4.08 \% \mathrm{~S}$, $\mathrm{PA}$ and $\mathrm{NC} 22^{\circ} \mathrm{C}$.

\section{CONCLUSION}

The drinking water quality of the villages Sellca, Gjerma, Shipkovica, Kodra e Diellit and the city of Tetova were monitored during a one year period. The results show that the highest water quality was recorded at the SEEU (DWQI = 92.69), whereas the lowest quality at Shipkovica (DWQI $=63.18$ ).

\section{ACNOWLEDGMENT}

The researchers acknowledge the financial support received from South East European University of Tetova and from the State University of Tetova, Macedonia.

\section{REFERENCES}

Akoto, O. and J. Adiyiah, 2007. Chemical analysis of drinking water from some communities in the Brong Ahafo region, Int. J. Environ. Sci. Tech., 4: 211-214. 
Alam, M. and J.K. Pathak, 2010. Rapid assessment of water quality index of ramganga river, western uttar pradesh (india) using a computer programme. Nature Sci., 8: 1-8.

Arunabh, M. and V. Bhatt, 2008. Physico-chemical and microbiological analysis of under ground water in V.V Nagar and Near by Places of Anand District, Gujarat, India. E-J. Chem., 5: 487-492.

Boyacioglu, H., 2007. Development of a water quality index based on a European classification scheme. Water SA, 33: 101-106.

CCME, 2001. Canadian water quality guidelines for the protection of aquatic life: CCME Water Quality Index 1.0 User's Manual. Canadian Council of Ministers of the Environment.

Chan, C.L., M.K. Zalifah and A.S. Norrakiah, 2007. Microbiological and physicochemical quality of drinking water. Malaysian J. Anal. Sci., 11: 414-420.

Chirila, E., T. Bari and L. Barbes, 2010. Drinking water quality assessment in constanta town. Ovidius Univ. Ann. Chem., 21: 87-90.

CWQCC, 2006. Colorado Water Quality Management and Drinking Water Protection Handbook. 1st Edn., Colorado Water Quality Control Commission, Denver, Colorado, pp: 80.

Dabevska-Kostoska, M., Dj. Fejzuli, M. Srbinovski, M. Ismaili and S. Aliu, 2007. Quality of drinking water in Dolni Polog region. Macedonian Ecol. Soc.

Durmishi, H.B., 2005. Master work, Determination of pollution degree of river waters Shkumbini (Pena) with heavy metals and other effluents with spectrometric method and stripping voltametry. University of Prishtina, Prishtina, Republic of Kosova.

GRM, 2004. Dri-nking water regulation official gazette republic of macedonia. Government of the Republic of Macedonia.

Krishnan, R.R., K. Dharmaraj and B.D.R. Kumari, 2007. A comparative study on the physicochemical and bacterial analysis of drinking, borewell and sewage water in the three different places of Sivakasi. J. En. Biol. January, 28: 105-108.

Li, L., P. Byleveld, A. Leask and W. Smith, 2009. Assessment of chemical quality of drinking water in regional New South Wales, Australia. Proceedings of the 18th World IMACS/MODSIM Congress, Jul. 13-17, Cairns, Australia, pp: 4326-4332.

Magnuss, V., 2009. Chemical composition and assessment of drinking water quality: Latvia case study. Proc. ECOpole 3: 267-272.
Napacho, Z.A. and S.V. Manyele, 2010. Quality assessment of drinking water in temeke district (part ii): Characterization of chemical parameters. Afr. J. Environ.. Sci. Technol., 4: 775-789.

Okonko, I., O. Adejoye, O. Damilola, O. Tolulope and A. Fajobi et al., 2008. Microbiological and physicochemical analysis of different water samples used for domestic purposes in abeokuta and Gojota, Lagos state, Nigeria. Afr. J. Biotechnol., 7: 617-621.

Ozdemir, C., E. Kalipci and S. Sahinkaya, 2010. Evaluation of bacteriological and chemical analysis of drinking water used in konya. Balwois 2010Ohrid, Republic Macedonia, Ohrid.

Parmar, K. and V. Parmar, 2010. Evaluation of water quality index for drinking purposes of river Subernarekha in Singhbhum District. Int. J. Environ. Sci., 1: 77-81.

Parvez, F., Y. Chen, M. Argos, A. Z. M. I. Hussain and H. Momotaj, 2006. Prevalence of arsenic exposure from drinking water and awareness of its health risks in a Bangladeshi population, results large population-based study. Eng. Health Perspectives, 114: 355-59. DOI: 10.1289/ehp.7903

Samantray, P., B.K. Mishra, C.R. Panda and S.P. Rout 2009. Assessment of water quality index in mahanadi and atharabanki rivers and Taldanda Canal in Paradip Area, India. J. Hum. Ecol., 26: 153-61.

Shilpi, S. and S. Gangal, 2010. Assessment of drinking water of different localities in Brij region: A physico-chemical study. Arch. Applied Sci. Res., 2: 157-164.

Thompson, T., 2007. Chemical safety of DrinkingWater: Assessing Priorities for Risk Assessment. 1st Edn., World Health Organization, Geneva, ISBN: 924154676X, pp: 142.

WHO, 2007. Chemical safety of drinking-water: Assessing priorities for risk management. Int. J. Environ. Stud., DOI: 10.1080/00207233.2011.565947

Yanggen, D.A. and S.M. Born, 1990. Protecting groundwater quality by managing local land use. J. Soil Water Conser., 45: 207-210.

Zamxaka, M., G. Pironcheva and N. Muyima, 2004. Microbiological and physico-chemical assessment of the quality of domestic water sources in selected rural communities of the Eastern Cape Province, South Africa. Water SA, 30: 333-340. 